\title{
Developing Indonesian language learning assessments: Strengthening the personal competence and Islamic psychosocial of teachers
}

\author{
Desi Sukenti ${ }^{1}$, Syahraini Tambak ${ }^{2}$, Charlina $^{3}$ \\ ${ }^{1}$ Department of Indonesian Language and Literature Education, Universitas Islam Riau, Indonesia \\ ${ }^{2}$ Department of Islamic Religion Education, Universitas Islam Riau, Indonesia \\ ${ }^{3}$ Department of Indonesian Language and Literature Education, Universitas Riau, Indonesia
}

\section{Article Info \\ Article history: \\ Received Apr 19, 2020 \\ Revised Sep 23, 2020 \\ Accepted Oct 29, 2020}

\section{Keywords:}

Indonesian language Islamic psychosocial Learning assessment Personality competence Teacher

\begin{abstract}
Research on the assessment of learning has been carried out by many other researchers, but putting Islamic psychosocial and personal competence as a solution has not been found. This study aimed to develop an assessment of Indonesian Language learning for high school teachers by strengthening Islamic psycosocial and personality competencies. Using the ex post facto approach, by distributing questionnaires to 213 Indonesian Language teachers and analyzed using descriptive and regression. This research results in the mastery of teachers about personality competence, Islamic psychosocial, and the assessment of Indonesian Language is the same as medium mastery. Personality competence and Islamic psychosocial as together are very strong in developing the ability to assessment Indonesian Language learning in high school teachers. Islamic psychosocial is predicted to be able to improve the assessment of Indonesian Language high school teacher learning as well as personality competence. This study concludes that personality's competences and Islamic psychosocial are very significant in developing the assessment of Indonesian Language high school teacher's in learning. This research contribution strengthens the development of the theory of "teacher performance assessment" in the world of education. For the Department of Education to develop policies to improve the assessment of Indonesian Language learning by conducting Islamic psychosocial and personality competency training for all teachers in Indonesia.
\end{abstract}

This is an open access article under the CC BY-SA license.

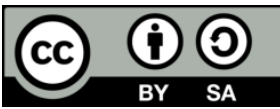

\section{Corresponding Author:}

Desi Sukenti,

Department of Indonesian Language and Literature Education,

Universitas Islam Riau,

24246 Jl. Kaharuddin Nasution 113, Marpoyan, Riau, Indonesia.

Email: desisukenti@edu.uir.ac.id

\section{INTRODUCTION}

Learning assessment is an important aspect in the world of education, because it is the key to success for teachers in bringing students to succeed in learning. The body of literature shows that the actual learning assessment activity is carried out not to look for mistakes or weaknesses based on the results of the evaluation of an object or program being evaluated, but the most important thing is to know the level of effectiveness of an object can run well and know the weaknesses that cause an object or program not can run well. So, it needs to be given a recommendation to be able to do improvements or improvements from the weaknesses found [1]. Learning assessments conducted by teachers consisting of cognitive, affective, and 
psychomotor work together to measure the success of learning managed by teachers, measure the level of student success in participating in learning activities, provide feedback for students and teachers, and selfevaluation of teachers and schools in managing learning [2].

Schools are required to develop reliable and credible student assessments to be the policies that surround them. Alimuddin's research [3] revealed that schools that neglected assessment had an impact on the potential creation and poor-quality standards of students. Assessment is seen as input obtained from the learning process that can be used to determine the strengths and weaknesses of the various components contained in a learning process [4]. In carrying out the assessment of educators need to be fair. This principle is followed by other principles so that the assessment can be done objectively, because fair assessment is not influenced by familiarity factors, but is carried out as a whole, has clear criteria, is carried out in the right conditions and with the right instruments as well, so as to be able to show learning achievement students as they are.

So far there have been several studies examining the assessment of teacher learning in various countries. Blanchet, et al. [5] research in Canada in Canada concerning teacher competency assessment that was strengthened along with occupational therapy with case study research. This study sees that the assessment of learning is still orthodox so it needs improvement. Kuranishi \& Oyler [6] research in Malaysia on the success of teachers using learning assessments involving school principals and students with a qualitative research approach. This study sees that teacher learning assessment is still problematic in determining criteria, instrument validity, and follow-up assessment results. Bouzid [7] revealed that the evaluation of learning carried out so far still tends to be on the cognitive aspect and is still low in the ability to make evaluation instruments given to students.

In Indonesia, there are several studies evaluating teacher learning in learning at school. Cahirunnisa's research [8] in 2018 in Palembang on improving the ability of students' self assessment by applying portfolio assessment with a class action research approach. This study sees that the assessment of student learning is very low so it needs improvement. Masrul's [9] study in Riau on evaluating students' writing abilities in learning English with a descriptive approach. In addition, Agustina, et al. [10] research in Jambi on the analysis of authentic assessment based on the 2013 curriculum in schools with a qualitative approach. This study sees that the assessments that occur still need improvement, especially in the apective and psychomotor aspects. Another study was carried out by Astuti \& Darsinah [11] in Surakarta on authentic curriculum-based assessment in 2013 in primary schools with a quantitative approach. This study sees that the assessment of learning in primary schools is still not in accordance with the principles of assessment theoretically so that it requires new applications in overcoming it.

Although several of studies have been found that examine the assessment of learning from various approaches and solutions, but this is still a problem for teachers in high school. Teachers-in most Indonesian high schools-still have difficulty in applying learning assessments to students, especially in terms of apective and psychomotor assessments, while learning outcomes of learners must be carried out fairly and accountably. Some teachers do not master the steps of learning evaluation in learning Indonesian so that it has an effect on the sincerity and sincerity of students' learning. It also appears in a variety of learning, most high school teachers are less consistent in using evaluation steps for students, while this becomes an integral part of a learning that must be implemented. The teacher also seems to lack the mastery of the use of learning evaluations, especially making question instruments and a fair assessment system.

To overcome this, solutions are needed with the assumption of providing personality competence and Islamic psychosocial to all high school teachers in Indonesia to increase teaching professionalism. In the theory of teacher personality competency that was raised by Rahayu \& Indra [12] is a steady, noble, wise, and authoritative personality ability and is an example of students who can become controllers in the learning process. While psychosocial in Erikson's theory [13] about human development states that human development applies continuously throughout his life through eight developmental ranks which he called psychosocial ranks. Islamic psychosocial according to Anwar [14] is a view that involves perceptions, motivations, beliefs and social interactions based on Islam to see a social problem that will affect the attributes of individual behavior in society.

This research examines the development of high school Indonesian language learning assessments by strengthening personal competence and Islamic psychosocial. This research is a new thing and has never been found in the world of education in Indonesia. Providing personality competence and Islamic psychosocial is a new value in the development of teacher assessment, especially in improving teacher professionalism. The research questions were formulated, namely: 1) How does the influence of teacher personality competencies in developing high school Indonesian Language learning assessments? 2) How is the Islamic psychosocial influence of teachers in developing the assessment of Indonesian high school teacher Indonesian learning? 3) How does personality competence and Islamic psychosocial influence in developing Indonesian language learning assessments for high school teachers? This study aimed to 
determine the development of high school Indonesian language learning assessment by strengthening the personal competence and Islamic psychosocial of Indonesian language teachers.

\section{RESEARCH METHOD}

This research was conducted with a quantitative design using an ex post facto approach [15] to explore the development of Indonesian language assessment by strengthening the Islamic psychosocial and personality competence of teachers. Ex post facto research does not require the commitment of high school teachers but sees the variables studied as understood and owned by high school teachers in the Indonesian learning process.

This research involved 213 Indonesian teachers spread across all high schools in Riau, Indonesia. Sampling using Slovin formula with a margin of error of 3\%. Purposive sampling is used to determine the sample used as research respondents. Questionnaire was used as a data collection technique related to personality competence, Islamic psychosocial and learning assessment. The questionnaire instrument was arranged based on the theory of personality competence, Islamic psychosocial and learning assessment. Personality competency instruments are arranged based on five dimensions; a steady personality, noble, wise, authoritative and be an example of students. Islamic psychosocial instruments are arranged based on three dimensions; perception, motivation, and belief and social interaction based on Islam. While the assessment is arranged based on three dimensions; cognitive, apective, and psychomotor assessments. A questionnaire instrument totaling 178 questions was tested and resulted value 85 for in a relativity.

Data were analyzed using descriptive analysis to examine the level of teacher understanding of Islamic psychosocial, personlaity competence and assessment of Indonesian language learning. While for inferential use to test hypotheses that have been built with regression, using SPSS version 24 .

\section{RESULTS AND DISCUSSION}

\subsection{Teacher personality competency profile}

Table 1 shows the stages of personality competencies from 213 teachers have maximum personality competencies (59\%). Based on Table 1, it is generally illustrated that the average level of personality competency of teachers in high schools Pekanbaru (mean $=51.95)$ with $(\mathrm{SD}=10.985)$. Value $($ mean $=51.95)$ seen at the level that has been set to be between (50-68) that is at the stage of the moderate category. Thus, it can be emphasized that the level of personality competency possessed by high school teachers in Pekanbaru is moderate.

Table 1. Level of teacher personality competence

\begin{tabular}{ccccccc}
\hline Variabel & $\mathrm{n}$ & Minimum & Maximum & Mean & Std. Deviation & Level \\
\hline Personality competence & 213 & 45 & 59 & 51.95 & 10.985 & Moderate \\
\hline
\end{tabular}

\subsection{Teacher Islamic psychosocial profile}

Table 2 shows the level of Islamic psychosocial mastery of high school Indonesian language teachers in Pekanbaru City. Islamic psychosocial mastery of Indonesian language teachers in high schools in Pekanbaru City is at a moderate level. This category can be seen in the value (mean $=201.39)$ with $(\mathrm{sd}=$ 27.003) where the mean value is between (174-217), which is in the medium category stage. This illustrates that Indonesian language teachers have Islamic psychosocial which is neither too high nor too low.

Table 2. Level of teacher Islamic psychosocial

\begin{tabular}{ccccccc}
\hline Variabel & $\mathrm{n}$ & Minimum & Maximum & Mean & Std. Deviation & Level \\
\hline Islamic psyichosocial & 213 & 166 & 285 & 201.39 & 27.003 & Moderate \\
\hline
\end{tabular}

\subsection{Teacher learning assessment profile}

Table 3 shows the level of mastery of learning assessment of Indonesian languge teachers in high schools in Pekanbaru City. Of the 213 teachers have mastery of evaluating Indonesian language learning with moderate mastery? This is shown on two things (mean $=108.77$; sd $=14.340$ ) where the average grading level of school teacher assessment above shows the mastery that is currently in accordance with predetermined categories, namely between 107-134. 
Table 3. Level of teacher learning assessment

\begin{tabular}{ccccccc}
\hline Variabel & $\mathrm{n}$ & Minimum & Maximum & Mean & Std. Deviation & Level \\
\hline Learning Assessment & 213 & 96 & 163 & 108.77 & 14.340 & Moderate \\
\hline
\end{tabular}

\subsection{The effect of personality competence on teacher learning assessment}

By using a simple linear regression test illustrated in Table 4 that there are values $(\mathrm{F}=9.672)$ and grades ( Sig. $=0.03=p<0.05$ ). This confirms that the research hypothesis which states that there is an influence of personality competence on the assessment of teacher learning in Indonesian Language in high school Pekanbaru is accepted. To see the magnitude of the influence of personality competence on the assessment of Indonesian language learning in high school teachers in Pekanbaru, Table 5 can illustrate that, where the value $(R=0.695)$ and value $(R$ Square $=0.483)$. This confirms that the effect of personality competence on the assessment of Indonesian language teachers' learning is quite strong.

Table 4. ANOVA

\begin{tabular}{ccccccc}
\hline & Model & Sum of Squares & df & Mean Square & F & Sig. \\
\hline 1 & Regression & 1717.998 & 1 & 1717.998 & 9.672 & $.003 \mathrm{~b}$ \\
& Residual & 9591.984 & 212 & 177.629 & & \\
& Total & 11309.982 & 213 & & & \\
\hline
\end{tabular}

Table 5. Model summary

\begin{tabular}{ccccc}
\hline Model & R & R Square & Adjusted R Square & Std. Error of the Estimate \\
\hline 1 & $.695 \mathrm{a}$ & .483 & .436 & 13.328 \\
\hline
\end{tabular}

The findings of this study indicate that the assessment of Indonesian language teacher learning can be developed quite strongly by strengthening personality competencies. This is not unreasonable, because in the results of Ayu \& Marzuki's research [16] that the construct of the teacher's personal competence compiled from Islam consists of the dimensions of al-iffah (unassuming), al-syaja'ah (courage), al-hikmah (wisdom) and al- 'adalah (justice) very supportive for assessment learning. The four dimensions will build teacher's personality comprehensively and give birth to hard work, gentle, generous and scientific behavior so that the assessment will have high accountability and validity. Szczygieł \& Weber [17] in their findings stated that someone who has perfect personality will have a good performance and is not affected by pressure, praise, and insults. They remain focused on work activities in accordance with the mandate given.

\subsection{The influence of Islamic psychosocial on the assessment of teacher learning}

Using a simple linear regression test is illustrated in Table 6 where there are values $(F=29.409)$ and values (Sig. $=0,000 ; \mathrm{P}<0.05)$. This confirms that the Islamic psychosocial has an influence on the assessment of Indonesian Language learning for high school teachers in Pekanbaru. Based on statistical analysis, the research hypothesis which states that there is an Islamic psychosocial influence on the assessment of Indonesian language learning in high school teachers in Pekanbaru is accepted. To see the magnitude of the influence of Islamic psychosocial on the assessment of Indonesian language learning of teachers in Riau Province High School, Table 7 can illustrate that, where the value $(R=0.892 \mathrm{a})$ and the value ( R Square $=0.795$ ). This confirms that the assessment of Indonesian teacher learning can be developed by a strong mastery of Islamic psychosocial. Because Islamic psychosocial influences the assessment of Indonesian language learning in the strong category in developing the assessment of high school teacher learning. Another thing shows Islamic psychosocial also has a strong relationship with the assessment of Indonesian high school teacher's Indonesian learning.

Table 6. ANOVA

\begin{tabular}{ccccccc}
\hline & Model & Sum of Squares & Df & Mean Square & F & Sig. \\
\hline 1 & Regression & 3987.796 & 1 & 3987.796 & 29.409 & $.000 \mathrm{~b}$ \\
& Residual & 7322.186 & 212 & 135.596 & & \\
& Total & 11309.982 & 213 & & & \\
\hline
\end{tabular}

Table 7. Model summary

\begin{tabular}{ccccc}
\hline Model & R & R Square & Adjusted R Square & Std. Error of the Estimate \\
\hline 1 & $.892 \mathrm{a}$ & .795 & .785 & 11.645 \\
\hline
\end{tabular}


These findings indicate that the assessment of Indonesian high school teacher's Indonesian learning can be developed with a comprehensive mastery of the psychosocial dimensions of Islam. The research findings are in accordance with the results of research found by Jacobs, et al. [18] psychosocial possessed by a person reinforces actions and attitudes to develop quality of work. Edwards, et al. [19] revealed that psychosocial factors play an important role in several taxonomic dimensions of human life. A person's psychology illustrates evidence that psychosocial variables play a key role in providing risk for behavioral development in shaping long-term adjustments, and modulating the results of self-development. Consideration of "general" psychosocial variables such as negative influences, childhood trauma, and social support, as well as "behavior-specific" psychosocial variables that include pain-related disasters, self-efficacy to manage emotional self, and scientific behavior.

\subsection{The influence of Islamic psychococial and personal competence on the assessment of teacher learning}

Using the regression test illustrated in Table 8 by looking at the value $(F=16.837)$ and the value (Sig. $=0.000 ; \mathrm{P}<0.05)$ confirms that Islamic psychosocial and personality competencies have an influence on the assessment of Indonesian language high school teachers' learning in Pekanbarubased on statistical analysis, the research hypothesis which states that there is an influence of Islamic personal and psychosocial competence on the assessment of Indonesian language learning in high school teachers in Pekanbaru is accepted. Table 9 illustrates the magnitude of the influence of Islamic psychosocial and personality competence on the assessment of Indonesian language learning of school teachers' senior high school all over Pekanbaru. Looking at grades $(\mathrm{R}=0.895 \mathrm{a}$; $\mathrm{R}$ Square $=0.801)$. This confirms that the influence of Islamic psychosocial and personality competence is simultaneously very strong in developing assessment of Indonesian language learning of teachers in high school. In addition, Islamic psychosocial and personal competencies also have a very strong relationship in developing teacher assessments in the field of Indonesian language studies. Another thing shows if the personality competence and Islamic psychosocial is applied by the teacher in the assessment of Indonesian language learning is predicted to experience a good increase. Table 10 shows, if the personal competence is mastered and applied by the teacher, it will improve the ability to assess Indonesian language learning by 0.465 or $46.5 \%$, and vice versa. Meanwhile, if Islamic psychosocial is implemented by the teacher, it will increase the ability to assess Indonesian learning by 0.577 or $57.7 \%$.

Table 8. ANOVA

\begin{tabular}{ccccccc}
\hline & Model & Sum of Squares & Df & Mean Square & F & Sig. \\
\hline 1 & Regression & 4394.062 & 2 & 2197.031 & 16.837 & $.000 \mathrm{~b}$ \\
& Residual & 6915.921 & 211 & 130.489 & & \\
& Total & 11309.982 & 213 & & & \\
\hline
\end{tabular}

Table 9. Model summary

\begin{tabular}{ccccc}
\hline Model & $\mathrm{R}$ & $\mathrm{R}$ Square & Adjusted R Square & Std. Error of the Estimate \\
\hline 1 & $.895 \mathrm{a}$ & .801 & .865 & 11.423
\end{tabular}

Table 10. Coofficients

\begin{tabular}{ccccccc}
\hline \multirow{2}{*}{ Model } & & \multicolumn{2}{c}{ Unstandardized } & Standardized & & \\
& & Coefficients & Coefficients & T & Sig. \\
& & B & Std. Error & Beta & & \\
\hline 1 & (Constant) & 66.809 & 16.836 & & 3.968 & .000 \\
& Kompetensikepribadian & .465 & .250 & .303 & 1.764 & .043 \\
& Islamic psychosocial & .577 & .161 & .521 & 4.529 & .000 \\
\hline
\end{tabular}

These findings indicate that the assessment of Indonesian language learning can be maximally developed by simultaneously mastering Islamic psychosocial and personality competencies by teachers in high schools. This is in accordance with the evaluation theory proposed by Richmond, et al. [20] that assessment of learning requires other factors for success both self and external conditions. Because valuation is a statement of value based on the perspective of the appraiser's developer. When accreditation institutions prioritize specific teacher quality indices (for example, disposition, core practices) and the problem of scalability and value neutrality are ignored, those who play a leadership role in teacher preparation programs may find themselves without the time, resources, and expertise needed to respond to considering external 
demands. The results may be a composite of judgments that are not useful for evaluative or learning purposes and may not reflect program or institutional values.

This could be because the learning assessment is related to the fate of a student whether or not, graduated or not, which is strongly influenced by the teacher's credibility and professionalism in assessing. Learning assessment influences the position and quality of the school so that personality and social skills are needed to maximize it comprehensively. Then the Islamic psychosocial and personality competencies are very appropriate to be held by Indonesian Language teachers to assess students' learning correctly, fairly, validly, accountable, and trusted. Both of these are efforts to overcome the ongoing challenges faced by Indonesian teachers-how to develop Indonesian assessments that are informative, measurable, and accepted by the majority of experts in this field.

If at the same time Islamic psychosocial and personality competencies are very high affecting the assessment of Indonesian language learning, the findings of this study predict that each has a different effect. Islamic psychosocial is predicted to have a high influence compared to personality competence in developing assessment of Indonesian Language learning of teachers in high schools. This is because in Islamic psychosocial theory it contains a person's abilities both individual, social, faith, morals, and self-organization, which are also partly contained in personality competence [21]. Islamic psychosocial theory includes involving perceptions, motivations, beliefs, and social interactions that are based on Islam to see a social problem that will affect the attributes of individual behavior in society. Human behavior must fulfill three things, namely: 1) the intrinsic Islam that is knowing the concept of the caliph, knowing the concept of selfexcellence, knowing the mission, building a mission, creating insight, commitment, identity, intelligence, ideals, luck, creativity, obsession, and worship; 2) social attitudes and perspectives which include prejudice, mutual trust, mutual support, cooperation, openness, defensive, closed, withholding information (consisting of non-cooperative and down appearance), living principles (consisting of material capital and spiritual capital), experience (consisting of positive and negative), interests (consisting of long-term and long-term), wisdom based on the rules of Allah SWT and His Messenger, comparison (high value standards, low value standards, objective and subjective), and literature (consisting of religion, philosophy and science); and 3) da'wah and self-valuesas true faith and confidence, istikhlas, ihsan (tawajuh), ihtisab, mujahadah nafsi, sure in the sentence of thayyibah, special prayer, knowledge of ma'azikir, ikromul Muslims, tashihunniyat, and da'wah wa al-tabligh [22].

Research findings of Bous, et al. [23] show that psychosocial possessed by a person greatly influences adaptation to the environment. Social factors are predicted to build relationships and attitudes of someone in implementing something new. Perceptions, attitudes, and personality factors are the main determinants of someone acting with high mobility. This is confirmed by the research findings of Preś, Kurpisz \& Pełka-Wysiecka [24] psychosocial factors associated with emotional reactions of gratitude and forms of expressing gratitude are closely related to the development of human personality. The level of gratitude is found to be positively correlated with self-esteem, emotional intelligence, and readiness to help people - both generous and others. Self-esteem, emotional intelligence, and readiness to help others are important aspects of the teacher's social psychology to develop maximum professionalism.

Karadağ's research [25] which confirms that the academic results of the course are evaluated by teacher grades or achievement tests. Psychosocial is very influential in improving student performance with fair assessment. The results showed that participation in outside courses increased students' relationships with peers and their lecturers, increased their motivation to attend classes, and helped them manage their stress. Teacher knowledge about psychosocial makes it easier for them to measure students' abilities from the aspect of social relations and psychology [26]. This is also reinforced by the research of Tjalla, et al. [27] that his findings on psychosocial are recommended to the government to facilitate school collaboration with universities in terms of the psychosocial ability of teachers to develop teacher assessments in schools.

Although the actual Islamic psychosocial is predicted to have a high influence compared to personality competence in the development of Indonesian language learning assessment, the level is not too much different. It is not also ignoring personality competence because its influence is predicted to be under Islamic psychosocial, but both of them equally contributed greatly in developing the assessment of Indonesian language in high school teacher's Indonesian learning assessment. Teacher personality competence in developing assessment in the findings of Kim, Jörg \& Klassen [28] requires special handling from the government to develop teacher professionalism. Questions about what makes a good teacher have been asked by practitioners, policy makers, and researchers for decades. However, there is no guideline framework on which qualities are important for teachers. Thus, it is necessary to examine these qualities using a recognized framework and to summarize the literature. The teacher's five personality domains (openness, awareness, extraversion, conformity, and emotional stability) and two outcomes related to teacher work (ie, teacher effectiveness and fatigue) must be owned by the teacher in assessment [29]. Next, the influence of three moderators, namely, types of measures of teacher effectiveness (ie, evaluation of teaching, 
self-efficacy of student performance, class observations, and academic achievement), sources of personality reports (ie, self-reports vs. other-reports), and the level of education instructed (i.e. basic, intermediate, and tertiary). Overall, the domain of the top five teachers (except for appropriateness) is positively related to teacher effectiveness, especially for teaching evaluation.

As the assessment of Indonesian language learning-in the findings of this study-is strongly influenced by personal perception, then for Rinawati, Kumaidi \& Harun [30] this competency must be developed. This personality competency development is elaborated from Islamic prophetic values to find indicators that can be used as references in developing assessment instruments. From the results of his research there are nine indicators of the prophetic personality based on a teacher, namely; 1) having a transcendent personality; 2) have a spirit of liberation; 3) humanists; 4) mastering the material to be taught; 5) having a good teaching method; 6) being able to be the ideal model for students; 7) able to evaluate with amarma'rufnahimunkar; 8) have a high commitment in carrying out tasks; 9) have good communication skills. These nine indicators strengthen the teacher's personal competence at various levels of education so as to increase the ability of teachers to assess learning well and quality.

Research of Jibeen, Baig \& Ahmad [31] is in line with the findings of this study that the moderate role of communicative competence and extraversion personality traits in the relationship between negative evaluation fear and understanding of communication in teaching Pakistani academics in their second language (English). Communicative competence and extraversion's personality traits significantly moderate the relationship between fear of negative evaluation and communication understanding. This finding has implications for instructors, campus advisers and researchers and academic policy makers who want to identify factors that can help academics overcome communication barriers, enrich learning experiences and enhance positive psychological functions in personality. So, in the results of Roloff, Klusmann, Lüdtke and Trautwein's [32] research revealed questions about which teacher personality characteristics explain the differences in the quality of teacher teaching is central to research on the quality of teaching and educational attainment of students. His research contributes to the existing literature on the quality of teacher teaching by investigating the role of teacher entry characteristics and teacher grades from teacher education based on longitudinal data regarding German secondary school teachers. Then the teacher must be prepared with good personality competence [33]. The personality characteristics of prospective teachers may be predictive of the quality of their teaching which must be further investigated in future research.

\section{CONCLUSION}

This research results that the mastery of personality competence, Islamic psychosocial and learning assessment abilities are the same in the medium category. Nevertheless, personality competences and Islamic psychosocial separately have different influences in developing high school teacher Indonesian learning assessment. Personality competence is quite strong (.483) affecting the assessment of Indonesian language teachers' learning. While Islamic psychosocial is really strong (.795) in developing teacher learning assessment in the field of Indonesian Language studies in high schools. Personality competence and Islamic psychosocial together is very strong (.801) in developing the ability to assess Indonesian language teachers' learning in high school. Personality competence is predicted to be able to increase the ability to assess Indonesian language learning by $(.465)$ or $(46.5 \%)$, while if Islamic psychosocial is applied by teachers, it is predicted to increase the ability to assess Indonesian language learning assessment by (.577) or (57.7\%). Islamic psychosocial is predicted to be higher than personality competence in developing the Indonesian Language assessment skills of teachers in high school. This study concludes that the mastery of teachers about personality competence, Islamic psychosocial, and Indonesian Language assessment is the same as medium mastery.

Personality competence and Islamic psychosocial together are very strong in developing the ability to assess Indonesian Language learning in high school teachers. Islamic psychosocial is predicted to be able to improve the assessment of Indonesian Language high school teacher learning as well as personality competence. The contribution of this research strengthens the development of the theory of "Teacher Performance Assessment" of Indonesian Language in education. The results of this study are recommended for the Department of Education to develop policies to improve the assessment of Indonesian Language learning by conducting Islamic psychosocial and personality competency training for all teachers in Indonesia.

\section{ACKNOWLEDGEMENTS}

Authors thanks to the Research and Community Service Institute for the Universitas Islam Riau, which has provided funding or an internal research grant from the Universitas Islam Riau. 


\section{REFERENCES}

[1] D. Divayana, "Evaluation of E-Learning Utilization Using the Cse-Ucla Model (in Bahasa)," Cakrawala Pendidikan: Jurnal Ilmiah Pendidikan, vol. 36, no. 2, pp. 280-289, 2017.

[2] Widiana, I. Wayan; Jampel, and I. Nyoman, "Learning Model and Form of Assesment toward the Inferensial Statistical Achievement by Controlling Numeric Thinking Skills," International Journal of Evaluation and Research in Education, vol. 5, no. 2, pp. 135-147, 2016.

[3] Alimuddin, "Assessment in the 2013 Curriculum (in Bahasa)," Prosiding Seminar Nasional Pendidikan Karakter, Universitas Riau, vol. 1, no. 1, pp. 23-33, 2014.

[4] S. McGrew, J. Breakstone, T. Ortega, M. Smith and S. Wineburg, "Can Students Evaluate Online Sources? Learning from Assessments of Civic Online Reasoning," Theory \& Research in Social Education, vol. 46, no. 2, pp. 165-193, 2018.

[5] M. Blanchet, T. Huynh, D. Giroux, and C. Bottari, "L'évaluation en ergothérapie pour contribuer à documenter l'aptitude: étude de CAS: Contribution of occupational therapy to the assessment of competence: A case study," Canadian Journal of Occupational Therapy, vol. 83, no. 3, pp. 154-165, 2016.

[6] A. Kuranishi and C. Oyler, "I failed the ed TPA," Teacher Education and Special Education, vol. 40, no. 4, pp. 299-313, 2017.

[7] Hassan Ait Bouzid, "An Evaluation of Selected Moroccan Elt Textbooks: A Standards-Based Approach Perspective," Indonesian Journal of Applied Linguistics, vol. 7, no. 1, pp. 229-238, 2017.

[8] Eva Dina Cahirunnisa, "Portfolio assessment in improving student self-assessment skills (in Bahasa)," Kalpataru, Jurnal Sejarah dan Pembelajaran Sejarah, vol. 4, no. 1, pp. 83-88, 2018.

[9] Masrul, "A Study of Students' Assessment in Writing Skills of the English Language," Jurnal Obsesi, vol. 1, no. 1, pp. 65-73, 2015.

[10] M. Agustina, Suraida, Alfian, and B. Syefrinando, "Authentic Assessment Analysis Based on The Curriculum 2013 at SMP Negeri 7 Muaro Jambi," Jurnal Biodik, vol. 4, no. 2, pp. 135-144, 2018.

[11] S. Astuti and Darsinah, "Authentic assessment based on the 2013 curriculum at SD Negeri Mangkubumen Kidul no. 16 Surakarta," Jurnal Managemen Pendidikan, vol. 13, no. 2, pp. 165-174, 2018.

[12] N. Rahayu and H. Indra, "Relationship between teacher's personality competence and principal supervision againts student with religious awareness," Tawazun: Jurnal Pendidikan Islam, vol. 10, no. 1, pp. 55-77, 2017.

[13] E. H. Erikson, Identity: Youth and crisis. New York: W.W. Norton, 1968.

[14] K. Anwar, "The mental-cognitive effects of Islam and the practice of the Sunnah through the intermediary of Islam psychosocial and Kendiri of Estim of self-attitude in self-control in adolescent practice problems (in Bahasa)," Disertasi, Universiti Kebangsaan Malaysia, 2014.

[15] J. Creswell, Educational research: Planning, conducting, and evaluating quantitative and qualitative. Oxford: Pearson Education, Inc., 2015.

[16] S. Ayu and Marzuki, "An assessment model of Islamic religion education teacher personality competence," Research and Educatin in Evaluation, vol. 3, no. 1, pp. 77-91, 2017.

[17] D. Szczygieł and J. Weber, "Emotional intelligence predicts peer-rated social competence above and beyond personality traits," Current issues in personality psychology, vol. 5, no. 2, pp. 91-101, 2017.

[18] R. Jacobs, M. Kane, and E. Sklar, "Psychosocial and Behavioral Correlates of Internalized Homonegativity in Midlife and Older Gay and Bisexual Men,” Journal of Applied Gerontology, vol. 39, no. 5, pp. 527-535, 2019.

[19] R. Edwards, R. Dworkin, M. Sullivan, D. Turk, and A. Wasan, "The Role of Psychosocial Processes in the Development and Maintenance of Chronic Pain,” The Journal of Pain, vol. 17, no. 9, pp. T70-T92, 2016.

[20] G. Richmond, M. Salazar, and N. Jones, "Assessment and the Future of Teacher Education," Journal of Teacher Education, vol. 70, no. 2, pp. 86-89, 2019.

[21] K. Friederika; R. Hains-Wesson, and Y. Karen, "Practical Typology of Authentic Work-Integrated Learning Activities and Assessments," Asia-Pacific Journal of Cooperative Education, vol. 18, no. 2, pp. 153-165, 2017.

[22] S. Tambak and D. Sukenti, "Strengthening Islamic behavior and Islamic psychosocial in developing professional madrasah teachers," Cakrawala Pendidikan: Jurnal Ilmiah Pendidikan, vol. 9, no. 1, pp. 65-78, 2020.

[23] Rany M. Bous, Rebecca A. Hazen, Irene Baus, J. Martin Palomo, Anand Kumar and Manish Valiathan, "Psychosocial Adjustments among Adolescents with Craniofacial Conditions and the Influence of Social Factors: A Multi-Informant Study," The Cleft Palate-Craniofacial Journal, vol. 57, no. 5, pp. 624-636, 2019.

[24] Joanna E. Preś, et al., "What Regulates Gratitude Response of Women and Men? The Role of the Received Good, Psychosocial Factors, and Repayment," Psychological Reports, vol. 123, no. 2, pp. 395-419, 2018.

[25] S. Karadağ, "Psychosocial Achievements of Social Studies Teacher Candidates in out door Geography CoursesCourses," Review of International Geographical Education Online, vol. 9, no. 3, pp. 663-677, 2019.

[26] S. Tambak, Madrasah Teacher Professionalism Development Model (in Bahasa). Yogyakarta, Graha Ilmu, 2020.

[27] A. Tjalla, et al., "The influence of the prevention, advocacy, distribution, repair, and adjustment functions of teacher guidance and counselling on the psychosocial conditions, self-reliance, and competence of high school students in DKI Jakarta province," International Journal of Education and Practice, vol. 8, no. 1, pp. 174-189, 2020.

[28] Lisa E. Kim, Verena Jörg and Robert M. Klassen, "A Meta-Analysis of the Effects of Teacher Personality on Teacher Effectiveness and Burnout," Educational Psychology Review, vol. 31, no. 1, pp. 163-195, 2019.

[29] S. Tambak, M. Yusuf Ahmad and D. Sukenti, "Strengthening Emotional Intelligence in Developing the Madrasah Teachers' Professionalism," Akademika: Journal of Southeast Asia Social Sciences and Humanities, vol. 90, no. 2, pp. 27-38, 2020.

Int. J. Eval. \& Res. Educ. Vol. 9, No. 4, December 2020: 1078 - 1087 
[30] A. Rinawati, Kumaidi, and Harun, "The integration of prophetic values in developing the teachers' personality competency assessment instrument," International Conference on Social Science and Character Educations (ICoSSCE 2018) and International Conference on Social Studies, Moral, and Character Education (ICSMC 2018), vol. 323, pp. 37-42, 2019.

[31] T. Jibeen, M. Baig, and M. Ahmad, "Fear of Negative Evaluation and Communication Apprehension: The Moderating Role of Communicative Competence and Extraversion Personality Trait in Pakistani Academia," Journal of Rational-Emotive \& Cognitive-Behavior Therapy, vol. 37, no. 1, pp. 185-201, 2019.

[32] J. Roloff, et al., "The predictive validity of teachers' personality, cognitive and academic abilities at the end of high school on instructional quality in Germany: A longitudinal study," AERA Open, vol. 6, no. 1, pp. 167-185, 2020.

[33] S. Tambak and D. Sukenti, "Tauhidization of Islamic Education: Contribution of the Divine Tawheed Education Model in Building the Face of Islamic Education (in Bahasa)" Madania: Jurnal Ilmu-Ilmu Keislaman, vol. 7, no. 2, pp. 154-173, 2018. 